Volume 21 Number 1 June 2021. P. 107-130

https://doi.org/10.30603/au.v21i1.2167

\title{
Historical Dynamics and Intellectual Networks of Pesantrens in Bangka Belitung Island Province in The Year 1930-2020
}

\author{
Hasan Asari ${ }^{1}$, Abd. Mukti $^{2}$, Subri ${ }^{3}$ \\ ${ }^{12}$ Universitas Islam Negeri Sumatera Utara \\ ${ }^{3}$ IAIN Syaikh Abdurrahman Siddik Bangka Belitung
}

\begin{abstract}
The focus of this article is to find out the historical dynamics and intellectual network of pesantren in Bangka. The research method is the historical method of Kuntowijoyo's theory. The result of the research is that the dynamics of the history of Islamic boarding schools in the province of the Bangka Belitung archipelago began with traditional Islamic educational institutions, namely reciting the Koran, then Arabic schools and then developing into Islamic boarding schools. The historical range of the growth of the Islamic boarding school is in accordance with the path of Islamization and the traditional characteristics of Bangka Islam. Meanwhile, the intellectual network of the pesantren of the Bangka community started from the Mecca and Middle East networks around the 1910s. Then the network shifted to its own country, which spread to parts of Sumatra, East Java, West Java and Kalimantan as well as the island of Bangka itself in the decade of the New Order era until post-reformation around the 1970s until now.
\end{abstract}

Keyword: historical dynamics, intellectual network, Pesantren, Bangka

\section{Dinamika Historis dan Jaringan Intelektual Pondok Pesantren di Provinsi Kepulauan Bangka Belitung Tahun 1930-2020}

\begin{abstract}
Abstrak
Fokus artikel ini adalah mengetahui dinamika historis dan jaringan intelektual pesantren di Bangka. Metode penelitiannya adalah metode sejarah teori Kuntowijoyo. Hasil penelitian adalah bahwa dinamika historis pondok pesantren di provinsi kepulauan Bangka Belitung berawal dari lembaga pendidikan Islam tradisional yaitu ngaji duduk/ngaji kitab lalu sekolah Arab kemudian berkembang menjadi pesantren. Rentang sejarah pertumbuhan pondok pesantren tersebut sesuai dengan jalur islamisasi dan karakteristik Islam tardisional Bangka. Sedangkan jaringan intelektual kaum pesantren masyarakat Bangka berawal dari jaringan Makkah dan Timur Tengah sekitar tahun 1910-an. Lalu jaringan intelektual tersebut beralih ke dalam negeri sendiri yang tersebar di wilayah sebagian Sumatera, Jawa Timur, Jawa Barat dan Kalimantan serta pulau Bangka sendiri pada dekade masa orde baru sampai pasca reformasi sekitar tahun 1970-an hingga sekarang.
\end{abstract}

Kata Kunci: Dinamika Historis, Jaringan Intelektual, Pesantren, Bangka

Author correspondence

Email: hasanasari@uinsu.ac.id

Available online at http://journal.iaingorontalo.ac.id/index.php/au/index 


\section{A. Introduction}

One of the unique $^{1}$ characteristics of traditional Islamic educational institutions in Indonesia, perhaps even in the world, is Islamic boarding schools because of their survival from time to time, then as the center of change $e^{2}$ and the education system ${ }^{3}$. Islamic boarding schools contain the meaning of Indonesian authenticity (indigenous) from a historical point of view so that they are identical with the meaning of Islam an sich. Therefore, discourse on pesantren is a space and discourse that is still worthy of being studied, studied, and presented in every generation in every era. Almost in all parts of Indonesia, there are Islamic boarding schools in villages, villages, cities, sub-districts, districts, provinces, and even the capital, so that Islamic boarding schools play a role in the intellectual life of the state and nation within the framework of the unitary state of the Republic of Indonesia. In this context, the island of Bangka also has Islamic boarding schools that have contributed a lot to the development of human beings who are knowledgeable, have good morals, and do good deeds for the socio-religious development of the people on this island.

Bangka Island, the province of the Bangka Belitung archipelago, is a new province that combines two islands, namely Bangka Island and Belitung Island, with an area of $16,424.06 \mathrm{~km} 2 .^{4}$ This area is ethnic Malay, called the Bangka Belitung Malays, who can live side by side with anyone. ${ }^{5}$ "The Malays of Bangka Belitung have accompanied the process of Islamization that took place on this island which was formed in one Bangka Malay custom who are the original

\footnotetext{
1 The uniqueness in question is the only traditional Islamic educational institution owned by Indonesia that can survive despite the currents of change and modernization of Islamic education in various regions of the Muslim world and still survive in carrying out its khittah, namely tafaqquh fi addiin.

2 Manfred Ziemek, Pesantren dalam Perubahan Sosial, (Jakarta: P3M, 1986), p. 2

3 Along with the course of history, that the education system of Islamic boarding schools underwent changes or distortions which from the beginning carried out the traditional education system (salafiyah), although later turned into a blend of traditional and modern (comprehensive), then changed it to a modern education system (kholafiyah or 'ashriyah). However, the boarding school education system will never fade from its traditional color (salafiyah) in its material content and approach.

4 Mely Agustini et al., Statistik Daerah Provinsi Kepulauan Bangka Belitung Tahun 2020, (Penerbit BPS Provinsi Kepulauan Bangka Belitung, 2020), p. 1

5 Akhmad Elvian, Memperkuat Jati Diri Melayu, dalam Mutiara Negeri Melayu, (Bangka Belitung: Madania Center Press, 2019.
} 
Historical Dynamics and Intellectual Networks of Pesantrens in Bangka Belitung Island Province in The Year 1930-2020

inhabitants of the island of Bangka." ${ }^{6}$ So, it is not difficult for pesantren to grow in this area because the Malay tribe is synonymous with Islam. Nearly $89 \%$ embraced Islam out of the total population in 2019 of 1,488,792 people ${ }^{7}$. However, the growth of pesantren on the island of Bangka has historically been different from the historical growth of pesantren in other areas such as in Java and others. This difference certainly has its reasons ${ }^{8}$ The people of Bangka Island are more familiar with referring to teachers/ustadz, rarely mentioning kyai for leaders/educators who manage or own Islamic boarding schools (Pondok Pesantren).

Some of the reasons identified from the dynamics that occur as mentioned above include; First, because of differences in the history of Islamization and Islamization channels in Bangka9. Second, the geographical differences in the area are thick with customs, terms, and the influence of traditional Islam on the island of Bangka in particular. Third, the difference in the meaning of the elements of the pesantren and the mention of the term kyai for leaders of Islamic boarding schools ${ }^{10}$. Fourth, because of differences in recitation culture and community characteristics. The four differences than do not distinguish the purpose and khittah of the Islamic boarding school as a whole, namely to explore the religious sciences ${ }^{11}$ or tafaqquh fi ad din. Within this framework, there is a diversification of the historical dynamics of the growth of pesantren, which has also colored the dynamics of the intellectual network of pesantren on the island of Bangka, the province of the Bangka Belitung archipelago.

Uncover the historical dynamics of Islamic boarding schools on the island of Bangka, which are closely related to the intellectual network of the pesantren/ulama as figures who play a role in the growth and development of

\footnotetext{
${ }^{6}$ Abdullah Idi, Bangka Sejarah Sosial Cina Melayu, (Yogyakarta: Tiara Wacana, 2011), p. 26-27

7 Mely Agustini et al., Statistik Daerah Provinsi Kepulauan Bangka Belitung Tahun 2020, (Penerbit BPS Provinsi Kepulauan Bangka Belitung, 2020), p. 1

${ }^{8}$ Of course, the differences in the origins of the growth of Islamic boarding schools on the island of Bangka do not obscure or even eliminate their original origins as happened on the island of Java, which was the beginning of the growth of Islamic boarding schools in Indonesia.

${ }^{9}$ Zulkifli, Kontinuitas Islam Tradisional di Bangka, cet. I, (Sungailiat: Shiddiq Press, 2007), p. 11-30

10 mention of kyai for the Bangka people is as a teacher, that the teacher from the perspective of the Bangka people has the same deep philosophical meaning as the kyai, namely the wise 'alim people have high religious knowledge and al-karimah morals (adab akhlak al-karimah).

${ }^{11}$ Lihat Haidar Putra Daulay, Sejarah Pertumbuhan dan Pembaruan Pendidikan Islam di Indonesia, Cet. 5, (Jakarta: Prenada Media Group, 2018), p. 70
} 
traditional institutions in this archipelago. Analyzing this matter is based on a study on the historicity of Islamic boarding schools that began with the growth of traditional Islamic institutions in the Bangka community and then developed into three models of Islamic boarding schools, namely traditional (salafiyah), then modern models (kholafiyah/'ashriyah) and integrated/comprehensive (imtijaz), so that then the style of the Islamic boarding school, the atmosphere, management, the education system is influenced and colored by the intellectual network and the dynamics of Islamization that occurred on the island.

\section{B. Research Method}

This journal article departs from a study using the historical method of Kuntowijoyo's theory. He explained that "there are five stages in the historical research process, namely; topic selection, source collection, verification (historical criticism and source validity), interpretation (analysis and synthesis) than writing - the data collection techniques using observation techniques, interviews, literature review, and documentation.

\section{Islamization and Historical Dynamics of Traditional Islamic Educational Institutions on Bangka Island, Bangka Belitung Islands Province}

The Bangka Belitung Islands autonomously became a province in 2000 consisting of 575 island groups so that the dominance of the sea is wider than the mainland. Approximately $79.90 \%$ of the total area is the ocean, only $20.10 \%$ island area. The province is divided into six regencies and one municipality located on two large islands, namely Bangka and Belitung. The Malay ethnic group, the majority Muslim, ranks first in the population, followed by the ethnic Chinese population. The religions in this province include Islam with the most prominent adherents of 1,233,654, Buddhism 67,718, Christianity 28,708 Kong Futchu 28,017, Catholicism as many as 18,701, religious beliefs 1,815, and Hinduism 1,154. Departing from the characteristics of the region, ethnicity, community, and religion, it indicates that the province of the Bangka Belitung archipelago is very welcome and appreciates multi-ethnic, ethnic, and religious groups. So it is not surprising then that the indigenous people "can mix well with the Chinese, 
assimilate and acculturate."12 Within the framework of tolerance, culture, and customs. This capital then made the development of Islam that occurred on this island did not encounter any significant obstacles. Likewise, Islamic educational institutions' historical growth and development with all their dynamics occurred naturally and naturally.

Revealing at a glance the development of Islam, which is a link in the growth and development chain of Islamic education on this island which was felt by all levels of society occurred around the second half of the 19th century "in the period of Banjar influence."13. Then periodically historically formed institutions in the form of Koran sitting, Arab schools, and pesantren. However, this development was preceded by the entry of Islam, which was identified through several lines of Islamization, including; 1). the Johor Malaysia route in the 16th century. 2). the Minangkabau route during the time of King Alam Harimau Garang, successively Sulaiman and Qori from Batusangkar14. 3), the Banten route in the second half of the 17th century. Since the death of King Alam Harimau Garang and when Sultan Agung Tirtayasa was in power (1651-1692) from Banten, the Regent of the Archipelago was sent as the Viceroy of Bangkakota ${ }^{15}$. 4). Palembang route, when the Regent of Nusantara died in 1671, his daughter Khadijah as the wife of Sultan Abdurrahman inherited power over the island of Bangka, then the Sindang Mahardika Law was made in Muntok under the arrangement of a Rangga. In these four initial paths, the emphasis of Islamization is concentrated on aspects of Islamic law and strengthening the political power of the kingdom. Then line 5). the path of the Banjar sultanate in the second half of the 19th century. 6). The influence of the Bangka people who go on the pilgrimage is increasing every year, so that they are "naon"16 Alternatively, "chronic," studying and studying religion in Mecca and the Middle East. So, the influence of the Middle East can be said to have

\footnotetext{
${ }^{12}$ Akhmad Elvian, Memperkuat ..., p. 1-2

13 Zulkifli, Kontinuitas Islam ..., p. 11-30

${ }^{14}$ Ma'moen Abdullah et al., Sejarah Daerah Sumatera Selatan, (Palembang: Proyek Inventarisasi dan Pembinaan Nilai-Nilai Budaya Provinsi Sumatera Selatan, 1991), p. 108

15 M. Arifin Mahmud, Sejarah dan Budaya Bangka, (Sungailiat: Materi Sarasehan Seni dan Budaya Daerah Kabupaten Bangka, 1994), p. 2-3

16 The term in the Bangka language refers to pilgrims who live for several years in Mecca. In addition to carrying out the obligatory Hajj, they use their time to study religion.
} 
colored the development of Islam in Bangka. 7). Javanese influence, in the historical record of the development of Islam in Bangka, is relatively new, namely the Javanese trade, some teach in public schools and madrasas, then around the early 20th century, some Bangka people stay in the modern Pondok Gontor and other huts; and 8). The Seribandung route, a pesantren in South Sumatra, has played a role in the development of Islam in Bangka through alumni and the output of this Islamic boarding school. The eight paths can be seen in the following scheme below:

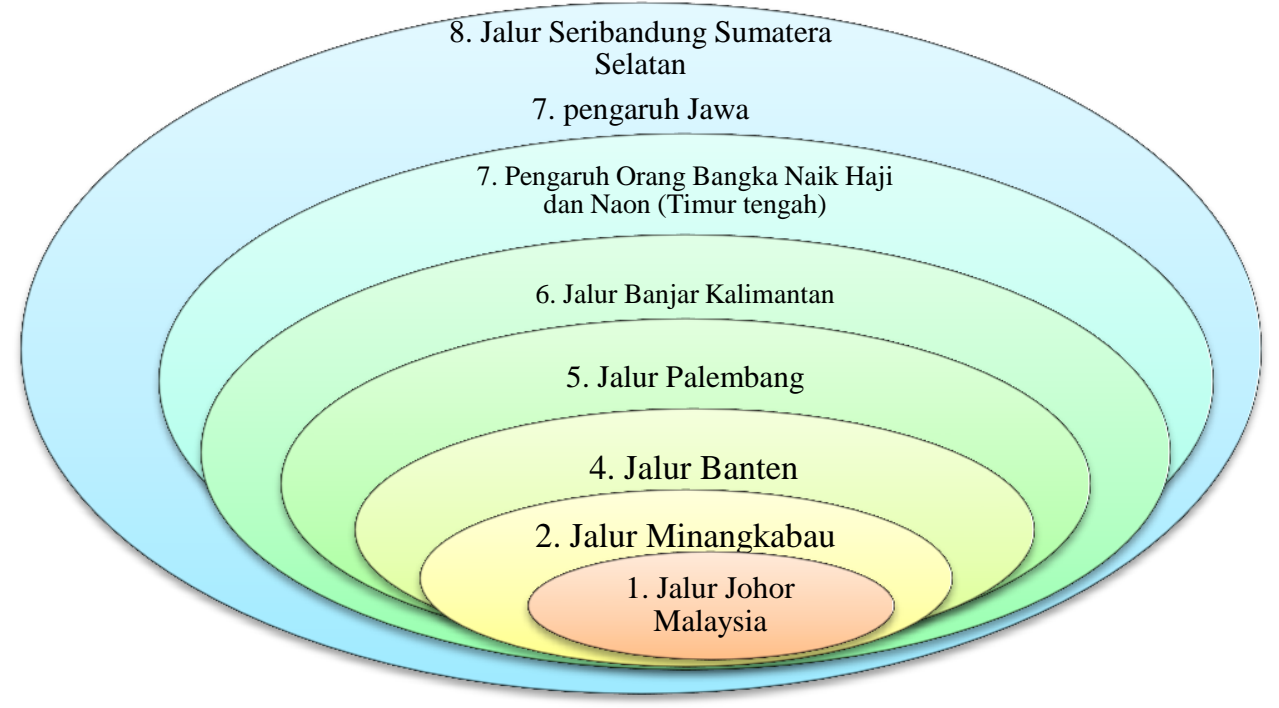

Summarizing these paths, the fifth, sixth, seventh, and eighth paths are the paths that form a new institutional system in the maintenance of traditional Islam in Bangka. However, the fifth path has begun to be felt and affects the people of Bangka's social and religious structure. Since the da'wah initiated by a cleric from Banjar, Haji Muhammad Afif al-Banjari, he was present on this island, precisely in Muntok, West Bangka, around the 1860s. Teaching and educating traditionally with the model of "reciting the Koran sitting/reciting the book."17 at home, and musholla or mosque. Then the da'wah was continued by his son, namely Shaykh Abdurrahman Siddik al-Banjari (1898-1910). Through da'wah bi al-lisan wa bi alqolam, it was at this time that Islam felt fast-growing on the island of Bangka. Bi al-

17 The term in the oral speech of the Bangka people refers to halaqoh or community recitation groups who study the yellow book such as fikih, akidah, at the teacher's house or the house of the recitation participant and or in the prayer room/mosque sitting facing the teacher who teaches 
lisan da'wah is done by educating, teaching, and preaching from house to house and or in the mosque with the Koran sitting/recitation model, which can then change the paradigm of people's religious understanding. Then da'wah bi al-qolam was done by producing written works in the form of books. There are at least 20 books that are written in Malay Arabic letters. While on the island of Bangka, he wrote no less than 8 of them Fath al-'Alim fi Tartib al-Ta'lim, written on 10 Sha'ban 1324 H, Risalah 'Amal Ma'rifah written in 1332 H, Tazkiratun li Nafsi wa li Amtsali as many as 39 pages, twenty Characteristics Schedule, Children's Lessons in Islam he wrote on one safar 1324 H/1906, Syarah Sittin Problems and Jurumiyah and Asrarus Sholah min'Iddah Kutub al-Mu'tamidah.

Tuan Guru was born in Dalam Pagar village, Martapura, South Kalimantan in 1857, died and was buried in Kuala Hidayat Tembilahan Indragiri Hilir Riau, 10 March 1939 at the age of 82 years. More or less for 12 years preaching, educating, and teaching on the island of Bangka ranging from 1898-1910. The author's analysis shows that there are at least four prominent roles of Sheikh Abdurrahman Siddik during preaching on the island of Bangka: First, through da'wah, teaching, and Islamic education, the flow of Islamization develops rapidly and widely. Second, as an active and productive teacher in writing, he has owned approximately 20 books of monumental works that the community has used to date. Third, as an appreciation and the actualization of his teachings and work, his name was immortalized as the name of the State Islamic Institute (IAIN) Syaikh Abdurrahman Siddik Bangka Belitung. Fourth, the application of his teachings by his students to continue studying in the holy city of Mecca and then it is locally called "naon" there. They are later generations who continue their teachings on the island of Bangka. Through informal teaching and education in the form of reciting the Koran, sitting/reciting the book both at home, prayer rooms/mosques, and cottages in the gardens held at that time, later inspired and initiated the pesantren education model in the following decades.

Around the year 1930, all the dynamics of the movement and the slices of historical values of education and teaching underwent changes and developments. So that in 1932, a kind of non-formal institution was formed, namely the "Arab school," which lasted until 1977/1978 and then changed its form to a pesantren. 
This is as emphasized by Ustadz Zaman Zahri, "that the forerunner of the pesantren on the island of Bangka was born from the existence of the Koran sitting or Koran reading (informal) then turned into an Arabic school (non-formal), then merged into a pesantren (formal) ${ }^{18}$.

Analyzing the above explanation, it is clear that before the formation of pesantren in Bangka, the province of the Bangka Belitung archipelago, historically, traditional Islamic educational institutions of the Bangka community had grown long before the independence period. Therefore the historical dynamics of pesantren on the island of Bangka, the islands of Bangka Belitung, and intellectual networks started from the pre-independence period, the independence period, the old order, and the new order reformation period. In the pre-independence period, traditional Islamic educational institutions grew informally, namely the Koran sitting/recitation of the book and then formed into a non-formal institution, namely Arabic schools, as explained below.

1. Sitting and Reciting the kitabs (ngaji kitab)

The chronology of the formation of this informal, traditional Islamic educational institution began with the traditional education and teaching system carried out by the ulema from Banjar Muhammad Afif al-Banjari the 1860s). Then in the next period was continued by his son, namely Shaykh Abdurrahman Siddik (1898-1910). The implementation of education and teaching takes place with the model of the Koran sitting/recitation of the book. Dhofier calls it halaqoh ${ }^{19} \mathrm{~A}$ teacher is surrounded by students in a semi-circle, sitting together on the floor on a mat or prayer rug. The teaching method is the bandongan/wetonan system; the students listened to the teacher read, translate and explain the book that became the teaching material. Historically this institution had grown long before the independence period, carried out in homes, mosques/musholla, and in huts in the teacher's garden. Across several eras, this traditional Islamic educational institution is still ongoing until now

\footnotetext{
18 Zaman Zahri, Senior dan penyejarah Pondok Pesantren Al-Islam, Interview, Pangkalpinang, 25 February 2020. Lihat pula Zulkifli, Kontinuitas Islam ..., p. 59

${ }^{19}$ Zamakhsyari Dhofier, Tradisis Pesantren Studi Pandangan Hidup Kyai dan Visinya Mengenai Masa Depan Indonesia, (Jakarta: LP3ES, 2011), p. 54
} 
developing in almost every region in the province of the Bangka Belitung archipelago.

During the time of Shaykh Abdurrahman Siddik, several areas on the island of Bangka which became centers of education and teaching of traditional Islamic educational institutions were first centered in Muntok, West Bangka, then Belinyu Bangka Induk, Kundi, Tempilang, Kotawaringin, Sungai Selan, Payabenua, Kemuja. and Big Pudding. Sea or river routes are more accessible transportation routes to reach and move from one area to another on the island of Bangka. So the areas mentioned are connected to sea or river routes which are the roadmap for Shaykh's educational da'wah. The mapping of the da'wah path can be seen more clearly on the map below.

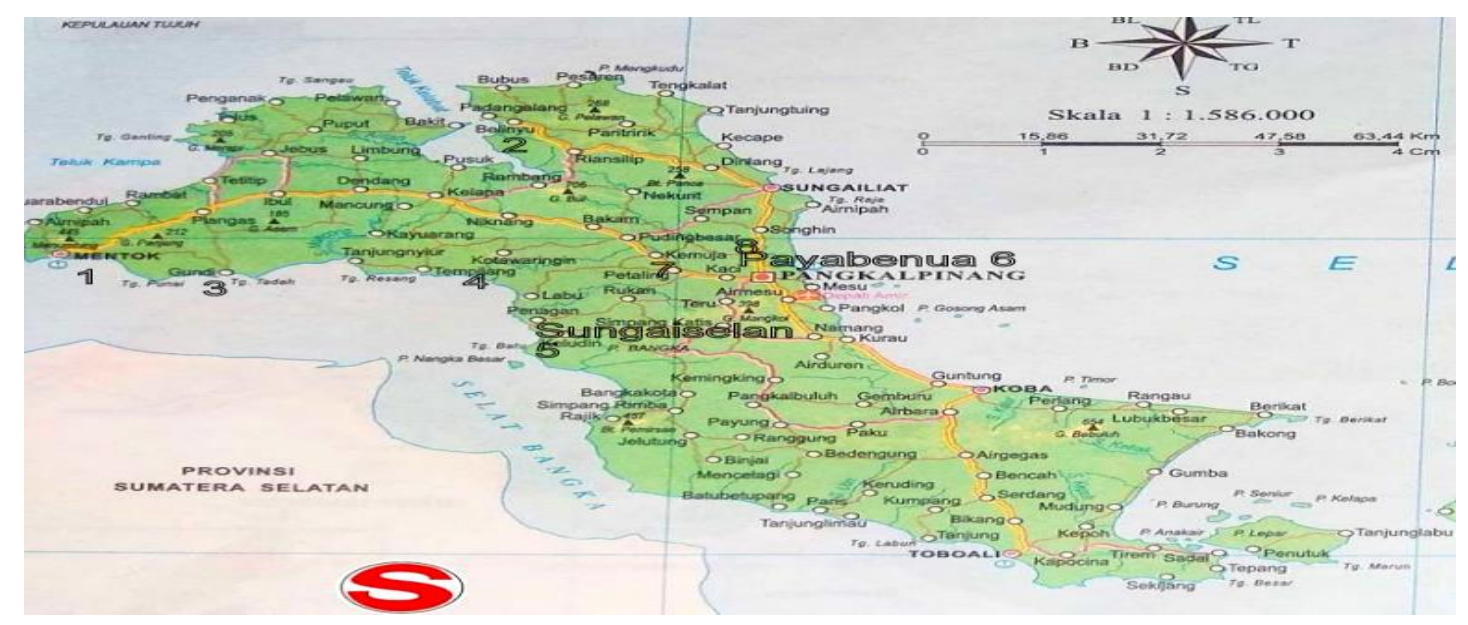

Note:

1. Muntok

2. Belinyu

3. Kundi

4. Tempilang Kotawaringin

5. Sungaiselan

6. Payabenua

7. Kemuja

8. Puding Besar

There is an educational institution for the Koran sitting/recitation of the book in each area, which Sheikh Abdurrahman Siddik carries out. Then, he 
migrated from the island of Bangka to the Indragiri Hilir area, Sapat Tembilahan, the Riau archipelago, precisely in Kuala Hidayat in 1910. "Next, this traditional Islamic educational institution is continued by its students who are naon in the holy city of Mecca and the Middle East. After they returned to their respective hometowns (1910-1932). Especially in the village of Kemuja Bangka, an area with a strong Islamic base, several groups reciting the Koran sit/recite the book has grown. It was also mentioned that in several areas on the island of Bangka, they carried out this Koran sitting/book reciting program by these inexperienced teachers." 20

As for the curriculum of traditional Islamic educational institutions, the Koran sits/recites the book, specifically, only studies Islamic religious materials. Using the yellow book or classic books of previous scholars. The curriculum can be seen in Table 1 below:

\begin{tabular}{|c|c|c|}
\hline No. & Name of the Kitab & Name of Author \\
\hline 1 & Sabil al-Muhtadin & Muhammad Arsyad al-Banjari \\
\hline 2 & Sifat Dua Puluh & Sayyid Utsman bin Abdullah \\
\hline 3 & Perhiasan Bagus & Sayyid Utsman bin Abdullah \\
\hline 4 & Al-Duur al-Nafis & Muhammad Nafis al-Banjari \\
\hline 5 & $\begin{array}{l}\text { Siru as-Salikin ila al-Ibadat al- } \\
\text { Alamin }\end{array}$ & Syaikh Abdussamad al-Palimbani \\
\hline 6 & Asror al-Sholah & Syaikh Abdurrahman Siddik \\
\hline 7 & Aqoid al-Iman & Syaikh Abdurrahman Siddik \\
\hline 8 & 'Amal Ma'rifah & Syaikh Abdurrahman Siddik \\
\hline 9 & $\begin{array}{l}\text { Pengajaran Agama Islam untuk } \\
\text { Kanak }\end{array}$ & Syaikh Abdurrahman Siddik \\
\hline
\end{tabular}

The implementation of education and teaching of the traditional Islamic educational institutions of the Bangka community, which has been going on through history, has existed from time to time until now. From the pre-

20 Zaman Zahri, Penuturan Lisan Tentang Sejarah Ngaji Duduk dan Pesantren di Desa Kemuja Bangka, 2020. 
independence period (1930), the independence period (1945), the old order/new order (1968-1998), then the reformation period (1998-until now). If accumulated since the presence of the teacher Haji Muhammad Afif al-Banjari (1860) and then his son Shaykh Abdurrahman Siddik al-Banjari (1898-1910), in the period (1860-2021), it has been almost 160 years. Throughout this age, this traditional Islamic educational institution still exists today. The following is a documentation of the implementation of education and teaching at traditional Islamic educational institutions of the Bangka community in the form of reciting the sitting and reading the book. Documentation was taken on March 14, 2021, in the village of Kemuja Bangka.

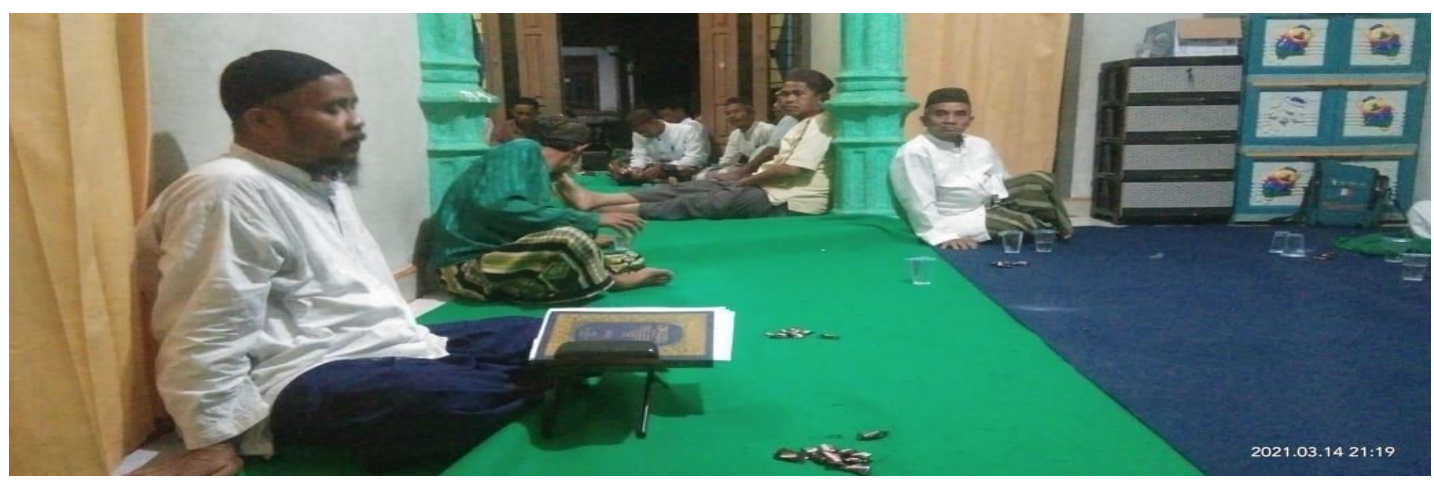

\section{Arabic School or Madrasah}

Historically, this Arabic (non-formal) school education institution grew and developed starting from implementing education and teaching at informal Islamic educational institutions, namely the Koran sitting/reciting the book. Where education and teaching of the Koran sit take place at homes, mosques, and prayer rooms as well as in cottages in the teacher's garden which takes place informally, then it develops into a non-formal Islamic educational institution, namely Arabic schools/madrasas along with many pilgrims who have joined the pilgrimage. The holy city of Makkah and the Middle East region returned to their homeland. The idea of renewing Islamic education in the form of classical non-formal educational institutions around 1932, around this year 
was predicted the beginning of the establishment of this Arab school educational institution. ${ }^{21}$.

This institution was established in the village of Kemuja Bangka to study classical Islamic religious education, which $\mathrm{H}$. Abdussomad founded, $\mathrm{H}$. Usman, H. Adam, and others. As Zaman Zahri said verbally, he explained that "the first students who studied at this institution were 30 people with very simple facilities ${ }^{22}$." Along with the development and the spirit of independence, in 1952, a madrasa was re-established in the village of Kemuja with the name Madrasah Ibtidaiyah al-Khairiyah. Then in 1968, this madrasah officially adopted the curriculum of the Ministry of Religion by studying several general subjects. This madrasa has a two-story building with four study rooms which was established in the same year.

In particular, the teaching curriculum of this Arab school is to learn the basics of Islamic religious teachings. The curriculum is as in table 2 below:

\begin{tabular}{|l|l|c|}
\hline No. & \multicolumn{1}{|c|}{ Subjects } & Classroom Level \\
\hline 1 & Al-Qur'an dan Tajwid & All level \\
\hline 2 & Bahasa Arab Dasar & All level \\
\hline 3 & Imla' / Dikte Arab & All level \\
\hline 4 & Ibadah 'Amaliyah & All level \\
\hline 5 & Ibadah Qouliyah & All level \\
\hline
\end{tabular}

As for concrete evidence of historical fragments of this Arab school building, especially in the village of Kemuja Bangka, as shown in the documentation of the building which is still standing and functioned for the Qur'an education level (Taman Pendidikan al-Qur'an - TPA) as below:

21 Zulkifli, Kontinuitas Islam ..., p. 56.

22 Zaman Zahri, Tenaga Pendidik Pesantren Al-Islam Kemuja, Interview, Pangkalpinang, 25 March 2020 


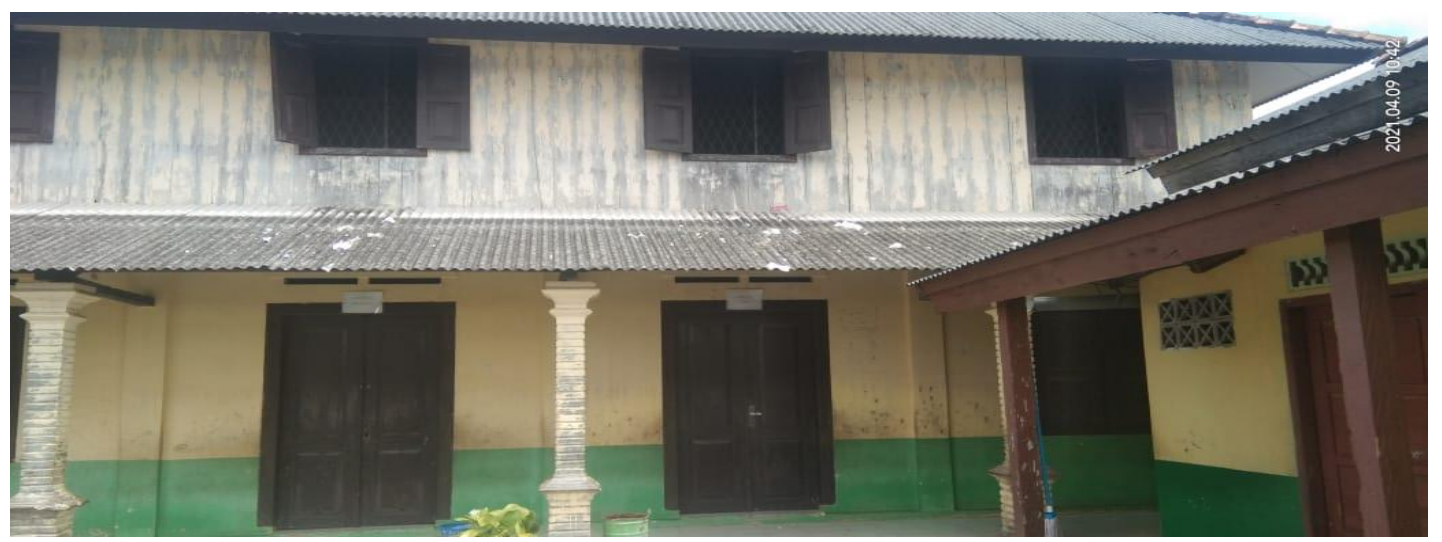

Departing from this madrasa by combining them and forming a formal Islamic educational institution, namely the Al-Islam Islamic boarding school. Around 1978 it officially became an Al-Islam Islamic boarding school. This Islamic boarding school was formed through the merger of several existing madrasas or educational programs ranging from the Diniyah Awaliyah Madrasah (1955), Ibtidaiyah Madrasah (1968), Tsanawiyah Madrasah (1976), and Aliyah Madrasah (1983). So, this Islamic boarding school has five levels of education, namely Al-Qur'an Education Park (TPA), Madrasah Diniyah Awaliyah (MDA), Madrasah Ibtidaiyah (MI), Madrasah Tsanawiyah (MTs) and Madrasah Aliyah (MA).

\section{Historical Dynamics of Islamic Boarding Schools on Bangka Island, Bangka Belitung Islands Province}

As explained above briefly, the historical dynamics of Islamic boarding schools originated from the implementation of education and teaching through informal, traditional Islamic educational institutions (reciting the Koran). Then formed a non-formal Islamic educational institution, Arab schools or madrasas, then developed into Islamic boarding schools. The historical range of growth and development has experienced and passed through several dynamic periods. The dynamics of growth and development of Islamic boarding schools on the island of Bangka, the province of the Bangka Belitung archipelago, can take place naturally. Although historically different in general with the historical growth of Islamic boarding schools such as in other areas such as Java and others. One of the Islamic boarding schools that started the dynamics of Islamic education and teaching on 
the island of Bangka is the Al-Islam Islamic boarding school located in the village of Kemuja Bangka.

Based on the historical dynamics of the growth of this Islamic boarding school, it started from the traditional Islamic educational institution of the Bangka community, namely the Koran sitting and reading the Koran. As previously explained, this Koran sitting educational institution has grown a lot in this village. This is because many Kemuja villagers went on a pilgrimage and later settled in the holy city of Mecca and the Middle East to study and study. At least they stay more than ten years. The data on some of the naon people include Abdussamad bin $\mathrm{H}$. Saman, Jemain bin H. Latif, Rozani bin Asir, Adam Malik, Ahmad bin H. Ladi, Ahmad bin H. Abu Bakr, Hasan, Azhari bin H. Nawawi, Ibrahim bin H. Nawawi, Mahrof bin H. Aban, Abdul latif bin H. Yusuf, Sya'i bin H. Idrus, Isman bin H. Buchori, Sahak bin H. Rasi, Sanusi bin H. Hasan, Junaidi bin H. Mat Amin , Abdurrasyid, Rais bin H. Abdurrasyid, Yahya, and Muhtar bin H. Yahya, so that in this village many open and carry out the Koran sitting/recitation of the book. In addition, this village community, in particular, is very enthusiastic and active in studying so that public acceptance of Islamic studies is very much appreciated and more readily accepted. In addition, the Malay culture of Islam with the indigenous Malay tribes of Bangka, who live in harmony, openness, and welcome, and the village of Kemuja is a robust Islamic base and center on the island of Bangka. These indications show how easy it is to establish Islamic educational institutions in this area and Islamic boarding schools, which the people of Bangka have long desired for their presence.

The people of Bangka are relatively new to the term Islamic boarding school. Around the 1970s, the term Islamic boarding school became familiar to the ears of the people of Bangka ${ }^{23}$. Since several Bangka people continue to study at the Sribandung Islamic boarding school, Palembang, South Sumatra. The boarding schools that started on the island of Bangka are the Al-Islam Kemuja Bangka Islamic Boarding School and the Nurul Ihsan Baturusa Islamic Boarding School Bangka. The historical fact of establishing this Islamic boarding school started from the traditional Islamic education and teaching process, namely the Koran sitting,

\footnotetext{
${ }_{23}$ Zulkifli, Kontinuitas Islam ..., p. 55
} 
Historical Dynamics and Intellectual Networks of Pesantrens in Bangka Belitung Island Province in The Year 1930-2020

then formed into an Arab school or madrasah and then became a boarding school. Approximately 58 Islamic boarding schools have been established, which periodically gradually grow and develop according to their time. The number of Islamic boarding schools is as shown in table 3 below:

\begin{tabular}{|c|c|c|c|c|c|}
\hline \multicolumn{2}{|c|}{ NO } & NAME INSTITUTION & $\begin{array}{l}\text { CLERIC/HEADMA } \\
\text { STER }\end{array}$ & ADDRESS & $\begin{array}{l}\text { FOUND } \\
\text { ED }\end{array}$ \\
\hline & & $\begin{array}{c}\text { KOTA } \\
\text { PANGKALPINANG }\end{array}$ & & & \\
\hline 1 & 1 & Darul Fatah & Khusnul Anam, Lc & $\begin{array}{l}\text { Jl. Dahlia Bukit } \\
\text { Merapen }\end{array}$ & 2006 \\
\hline 2 & 2 & Hidayatussalikin & A. Jakfar Shiddiq & Jl. Pantai Pasir Padi & 1999 \\
\hline 3 & 3 & Syaikhona Kholil 2 & Ahmad Zaini & Jl. Basuki Rahmat Taib & 2001 \\
\hline 4 & 4 & Darussalam & Drs. M. Luthfi & $\begin{array}{l}\text { Jl. Ahmad Yani Dalam } \\
\text { No. } 36\end{array}$ & 1986 \\
\hline 5 & 5 & Nurul Hidayah & Abdul Manaf & $\begin{array}{l}\text { Jl. Berlian Vi Rt/Rw. } \\
07 / 02\end{array}$ & 1993 \\
\hline 6 & 6 & $\begin{array}{l}\text { Ma`had Tahfidzul } \\
\text { Qur`an }\end{array}$ & $\begin{array}{l}\text { Abu Hasanudin, } \\
\text { S.Pd.I }\end{array}$ & Jl. H. Bakri No. 38 & 2008 \\
\hline \multirow[t]{2}{*}{7} & 7 & Mamba`ul Ulum & Rozali & Jl. Kampung Melayu & 1974 \\
\hline & & KABUPATEN BANGKA & & & \\
\hline 8 & 1 & $\begin{array}{l}\text { Ponpes Plus Bahrul } \\
\text { Ulum }\end{array}$ & Ust. Suhaimi & $\begin{array}{l}\text { Jl. Matras Lama } \\
\text { Sungailiat }\end{array}$ & 1999 \\
\hline 9 & 3 & At Toyyibah & Ust. Ibrohim & Desa Balun Ijuk & 2015 \\
\hline 10 & 4 & Miftahul Ulum & KH. Muhsin Alwi & Dusun Tiang Pulut & \\
\hline 11 & 5 & Al Islam & $\begin{array}{l}\text { KH. A. Hijazi } \\
\text { Djama'in }\end{array}$ & Jl. Raya Mentok & 1979 \\
\hline 12 & 6 & Sabilul Muhtadin Jada & Ust. Zulkarman & Kampung Jada Bahrin & 1989 \\
\hline 13 & 7 & Nurul Muhibbin & KH. Zainawi & Kemuja & 1999 \\
\hline 14 & 8 & Darunnnajah & Ust.Ibnu Mahlub & Paya Benua & 2004 \\
\hline 15 & 9 & Riyadhul Jannah & $\begin{array}{l}\text { Ust. M. } \\
\text { Yazanuddin }\end{array}$ & Jl. Raya Kayu Besi & 2006 \\
\hline 16 & 10 & Daarul Abror & $\begin{array}{l}\text { H. Sofyan Abu } \\
\text { Yamin }\end{array}$ & Desa Kace & 2009 \\
\hline 17 & 11 & $\begin{array}{l}\text { Ma`had Islam } \\
\text { Jamalullail }\end{array}$ & Fita & $\begin{array}{l}\text { Jl. Ma`had Islam } \\
\text { Jamalullail }\end{array}$ & 2013 \\
\hline 18 & 12 & Hidayatul Qur`an & $\begin{array}{l}\text { Ust. Mashuri, Lc, } \\
\text { MA }\end{array}$ & $\begin{array}{l}\text { Jl. Raya Mentok Puding } \\
\text { Besar }\end{array}$ & 2013 \\
\hline \multirow[t]{2}{*}{19} & 13 & Ilzamun Maju Bahrin & Husnul Baqi & Jalan taman hutan raya & \\
\hline & & $\begin{array}{c}\text { KABUPATEN BANGKA } \\
\text { TENGAH }\end{array}$ & & & \\
\hline 20 & 1 & Almuhajirin & $\begin{array}{l}\text { Ust. Sahbudin } \\
\text { Achmad }\end{array}$ & $\begin{array}{l}\text { Jl. Pesantren Simpang } \\
\text { Perlang }\end{array}$ & 1987 \\
\hline 21 & 2 & Nurul Falah & $\begin{array}{l}\text { Masri Saharun, } \\
\text { S.Pd.I }\end{array}$ & Jalan Pangkol Rt. 08 & 1990 \\
\hline 22 & 3 & Bahrul Huda & $\begin{array}{l}\text { H. Ayatullah Mirza } \\
\text { K. }\end{array}$ & Jalan Raya Sungaiselan & 2001 \\
\hline
\end{tabular}




\begin{tabular}{|c|c|c|c|c|c|}
\hline 23 & 4 & $\begin{array}{l}\text { Raudlatul Muta`allimin } \\
\text { Al-Baisuny }\end{array}$ & Marju'ien & Desa Jelutung & 2010 \\
\hline 24 & 5 & Hidayatullah & $\begin{array}{l}\text { Irwan Sambasong, } \\
\text { S.Pd.I }\end{array}$ & Jl.Desa Teru & 2013 \\
\hline 25 & 6 & Roudhlotul Hidayah & Hasib Syafi'ie & Desa Jeruk & 2012 \\
\hline 26 & 7 & Darurrohmah & $\begin{array}{l}\text { Drs. H. Ahmad } \\
\text { Sofyan }\end{array}$ & Desa Lubuk Besar & 2010 \\
\hline 27 & 8 & Riyadhul Muhibbin & & $\begin{array}{l}\text { Jalan Raya Desa } \\
\text { Namang }\end{array}$ & \\
\hline 28 & 9 & Ainul Muhibbin & Ahmad Maliki & Jl. Raya Desa Puput & 2003 \\
\hline 29 & 10 & Nurul Ulum & Munir & Desa Bukit Kijang & 2002 \\
\hline 30 & 11 & Nurul Hidayah & H. Ahmad Fathoni & Desa Tanjung Pura & 2006 \\
\hline \multirow[t]{2}{*}{31} & 12 & Roudlatul Muttaqin & Abd shomad & Desa Namang & 2007 \\
\hline & & $\begin{array}{l}\text { KABUPATEN BANGKA } \\
\text { BARAT }\end{array}$ & & & \\
\hline 32 & 1 & Ta`limul Muta`alim & IMAM SUHADAK & Gg. Balai Ds Airkuang & 2014 \\
\hline 33 & 2 & Miftahul Khoir & PARDI & JALAN AMD & 1996 \\
\hline 34 & 3 & Miftahul Jannah & & Km.33 Desa Pelangas & 1979 \\
\hline 35 & 4 & Madinatul Ilmi & & Desa Sangku & 2009 \\
\hline \multirow[t]{2}{*}{36} & 5 & Darut Taklim & Azas Kasali & $\begin{array}{l}\text { Dusun Riang Desa } \\
\text { Kundi }\end{array}$ & 2016 \\
\hline & & $\begin{array}{l}\text { KABUPATEN BANGKA } \\
\text { SELATAN }\end{array}$ & & & \\
\hline 37 & 1 & Yppm Al-Hidayah & Drs Kusrin & Jl. Gadung Toboali & 1987 \\
\hline 38 & 2 & Darus Syafa`ah & $\begin{array}{l}\text { Ahmad Shobirin } \\
\text { A.Ma }\end{array}$ & $\begin{array}{l}\text { Rt } 03 \text { Rw } 02 \text { Desa } \\
\text { Sidoharjo }\end{array}$ & 2000 \\
\hline 39 & 3 & Tarbiyatul Mubtadiin & Rosyidi Mahfudz & Jl. Merdeka No. 21 & 2008 \\
\hline 40 & 4 & Miftahunnajah & H. Yanto, S.Pd.I & Jl Raya Km 10 & 2006 \\
\hline 41 & 5 & Darul Hikmah & Fuadi Jama`in & Jln. Pesantren & 1989 \\
\hline 42 & 6 & Nurul Quran & Syamsul Hadi & Desa Sidoharjo & 1998 \\
\hline \multirow[t]{2}{*}{43} & 7 & Darul Istiqomah & Apriyadi, S.Pd.I & $\begin{array}{l}\text { Jl. Pesantren Desa Air } \\
\text { Gegas }\end{array}$ & 2012 \\
\hline & & $\begin{array}{l}\text { KABUPATEN } \\
\text { BELITUNG }\end{array}$ & & & \\
\hline 44 & 1 & Fathurrahman & $\begin{array}{l}\text { Khairul Anam, } \\
\text { S.Th.I }\end{array}$ & Jl. Munir No. 34 & 2000 \\
\hline 45 & 2 & Daarul Arofah & $\begin{array}{l}\text { K.H.Muhammad } \\
\text { Ali Haries, S.Pd.I }\end{array}$ & $\begin{array}{l}\text { Jalan Tanjung Tinggi } \\
\text { Desa Keciput }\end{array}$ & 2000 \\
\hline 46 & 3 & Baitussalam & Khabib Achmad & Jl. Kesehatan & 2000 \\
\hline 47 & 4 & At Taqwa & Mulyadi Ibrahim & $\begin{array}{l}\text { Jl. Air Ketekok Gang } \\
\text { Pinang }\end{array}$ & 1996 \\
\hline 48 & 5 & Achmad Dahlan & $\begin{array}{l}\text { H. Ana Suryana, } \\
\text { S.Pd.I }\end{array}$ & $\begin{array}{l}\text { Jl. K.H Achmad Dahlan } \\
\text { Km. } 4,5\end{array}$ & 2003 \\
\hline \multirow[t]{2}{*}{49} & 6 & Madinah El Wihdah & M.Hizbullah, Lc & Jl. Air Saga Ds. Air Saga & 2002 \\
\hline & & $\begin{array}{c}\text { KABUPATEN } \\
\text { BELITUNG TIMUR }\end{array}$ & & & \\
\hline 0 & 0 & $\mathbf{0}$ & 0 & 0 & \\
\hline
\end{tabular}


Summarizing the narrative of the historical dynamics of the traditional Islamic educational institutions of the Bangka community above, the process started from the existence of the Koran sit/recitation institution, then developed into an Arab school/madrasah as happened in the Kemuja and Baturusa areas, then accumulated/gathered to form a boarding school. In the context of the research conducted with a locus of three Islamic boarding schools representing the types of Islamic boarding schools, namely traditional (salafiyah), modern ('ashriyah) and comprehensive (imtijaz), namely the Nurul Muhibbin Islamic Boarding School, Daarul Abror Islamic Boarding School, and Al-Islam Islamic Boarding School. The historical dynamics of the Al-Islam Islamic boarding school proceeded from the traditional Islamic educational institutions of the Bangka community, namely, the Koran sitting and recitation of the book, then Arabic schools, and then forming a pesantren. Then the Nurul Muhibbin Islamic boarding school proceeded from reciting the Koran and then becoming a pesantren, while the modern Daarul Abror boarding school started from providing pesantren buildings and then accepting students. According to their period, the three pesantrens were formed, namely the pre-independence period, the old and new order period, and the reformation period. In the following diagram below, historically can be made the organizational structure of traditional Islamic education in Bangka.

Diagram 1: Traditional Islamic Education-Organizational Structure in Pulau

\section{Bangka}

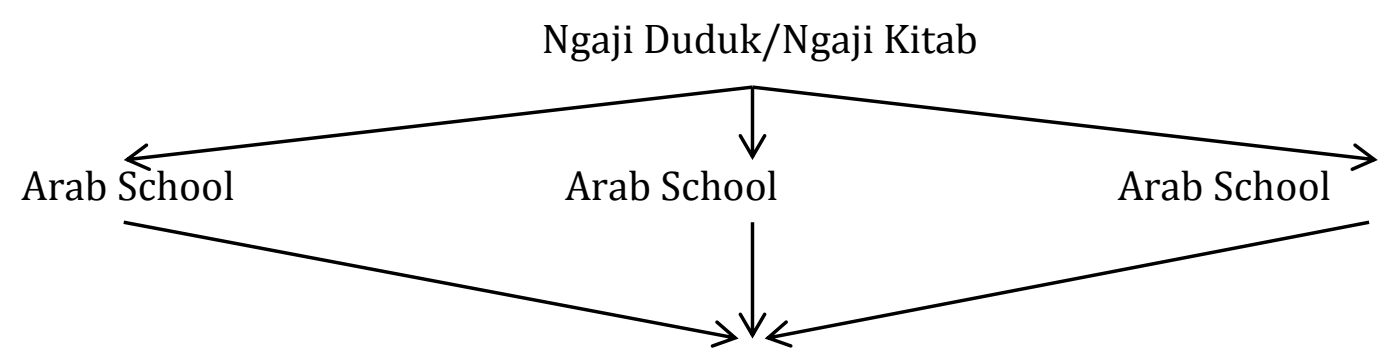

Pondok Pesantren - Ponpes (Islamic Boarding School)

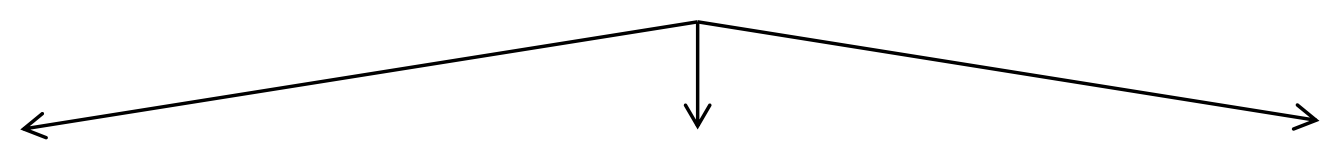

Ponpes Salafiyah

Ponpes Komprehensif

Ponpes Modern

(Nurul Muhibbin)

(Al-Islam)

(Daarul Abror) 


\section{E. Intellectual Network of Islamic Boarding Schools in Bangka Belitung Province}

Discourse on intellectual networks or intellectual chains of pesantren. Dhofier explained that building the solidity of the intellectual chains can be done through the following three practical ways; "First, develop the tradition that the closest family must become a strong cadre or candidate as a substitute for the leadership of the pesantren. Second, developing the endogamous principle, namely a network of marriage alliances between the kyai's family. ${ }^{24}$. Third, through the transmission of knowledge or intellectual networks or intellectual transmission chains between fellow kyai and families. Alternatively, through a chain of learning resources (where, when, to whom, and the connection of the scientific chain). However, the intellectual network of the pesantren in Indonesia has generally been established since the 16th and 17th centuries, especially the third-order learning network, according to Dhofier. As Johns ${ }^{25}$ mentioned that the "ulama" in Indonesia in that century had corresponded with the scholars in Saudi Arabia. They invited Indian and Arab scholars by bringing many books such as commentaries, fiqh, and others. Likewise, Acehnese scholars and other regions went to Mecca to perform Hajj and stayed for some time in the Hejaz and Yemen to study religion.

Referring to the explanation above, in the historical perspective of Bangka Belitung, the formation of pesantren is a different process from that of other regions. In addition, the mention of kyai in the dialect of the Bangka people is not familiar, but the people of Bangka are more familiar with calling it guru. A person who teaches at a traditional Bangka educational institution and owns a pesantren teaches and manages it. Then it is infrequent for marriages between kyai/teacher families in Bangka. Therefore the intellectual network analysis is more on the aspects of the teacher's learning network, scientific sanad, and learning areas. As the results of observations made, it can be identified that the intellectual network of learning of the pesantren on the island of Bangka through 5 channels, namely;

\footnotetext{
24 Zamakhsyari Dhofier, Tradisi Pesantren Studi Pandangan Hidup Kyai dan Visinya Mengenai Masa Depan Indonesia, cet. 2, (Jakarta: LP3ES, 2011), p. 101

25 AH. Johns, From Coastal Settlement to Islamic School and City: Islamization in Sumatera, The Malay Peninsula, and Java, in J Fox (ed.) Indonesia: The Making of A culture, School Seminar Series No.2, (Canberra: Research School of Pacific Studies, ANU, 1980), h. 168. Lihat pula Dhofier, Tradisi Pesantren ..., p. 129
} 
The South Sumatra route is Palembang, the Java route, the Madura route, the Kalimantan route, and the Sunda route. However, the intellectual network of learning, especially the Bangka community, started from Makkah and the Middle East network. In around 1910, many Bangka people performed the pilgrimage, then some of them lived "naon" in the holy city of Mecca and parts of the Middle East to study and gain knowledge. So that the original network of pesantren on the island of Bangka, which started from traditional educational institutions and then formed Islamic boarding schools, was an intellectual network of Mecca and the Middle East ${ }^{26}$. After the introduction of Islamic boarding schools by the Bangka people around the 1970s, the learning community spread to several Islamic boarding schools in Indonesia according to the intellectual pathways mentioned above.

These routes can be explained, including the South Sumatra route, especially Palembang, which started the introduction and contact of the people of the island of Bangka to know pesantren. Around the 1970s the people of Bangka had started studying at the Nurul Islam Seribandung Islamic boarding school, Ogan Komering Ilir, South Sumatra. When the pesantren reached the peak of progress with the number of students in the thousands, it was widely known in several areas of South Sumatra, including Bangka at that time. The Bangka area where many people live in this pesantren includes the villages of Kemuja, Pangkalpinang, Baturusa, and others. Then the Java route, as the pesantren became known, also included many Bangka people studying in the Java area, especially East Java, namely the modern Daarussalam Gontor Ponorogo boarding school. Then Probolinggo, Jombang and others. There are several areas where many students are studying at this lodge, such as the village of Kemuja, Puding Besar, Pangkalpinang, and some other areas.

Furthermore, on the Madura route, many Bangka people studied in Madura around the 90s. The indications can be seen from several Islamic boarding schools that have been established and exist on the island of Bangka, such as Islamic boarding schools located in the Central Bangka region and Kayu Besi

26 Zaman Zahri, Saksi Sejarah dan Tenaga Pendidik Pesantren Al-Islam Kemuja, Interview, Pangkalpinang, 25 Maret 2020. 
village, Puding Besar sub-district, Bangka. Then the Kalimantan route, around the mid-late 90s, many Bangka people also studied in South Kalimantan, especially the Martapura area and its surroundings. Bangka areas that have learned a lot in this area include the districts of Puding Besar, Kemuja, Petaling, Mendobarat, Cengkong Abang, Pangkalpinang and several other areas. Then the Sunda route including Cirebon, Tasikmalaya, and the surrounding area. The indications can be seen from several Islamic boarding schools in South Bangka Regency, owned and managed directly by the leaders and their teaching staff from Cirebon, Tasikmalaya, and surrounding areas.

The analysis of the path above is based on the learning chain of the pesantren of the Bangka community and the place where they gain knowledge since the term pesantren is familiar to the Bangka community. Since the 1970s, the people of Bangka initially did not see what type of Islamic boarding school they were, whether salafiyah or modern or a combination, the most important thing is that they can learn to gain religious knowledge. ${ }^{27}$. However, in the decade of the 2000s, the people of Bangka began to sort out which type of Islamic boarding school had the more significant trend and interest for the people of Bangka. Around the end of the 90s, the Bangka route began, where many Bangka people sent their children to Islamic boarding schools on the island of Bangka. Many of the alumni then participate in the world of education as educators or lecturers, da'wah, and missionaries. Some are leaders of Islamic boarding schools such as the Nurul Falah Air Mesu Islamic Boarding School in Central Bangka and others so that since then, not many Bangka people have studied in Islamic boarding schools outside the region.

Analyzing the statement above, that the intellectual network of the Bangka community pesantren started from the Mecca and Middle East networks around

\footnotetext{
27 This data is obtained from the results of observations and an oral speech from several parents whose children study in Islamic boarding schools throughout Indonesia, including Puding Besar, Kemuja, Pangkalpinang, Petaling, and Mendobarat areas. The substantial reason for their children to enter the Islamic boarding school is the choice of parents based on the influence of other parents who mainly send their children to which boarding school in their village. So that it is easier for their children to interact with each other in the same area, exchange information with each other. As well as the convenience, tranquility, and trust of parents to their children if many are from the same village or study area in the same Islamic boarding school. In the decade of the 2000s, the people of Bangka preferred to choose the type of Islamic boarding school that had a habib.
} 
the 1910s until the post-independence period. Then during the old order in 19451965 and the new order in 1966-1998. Then the intellectual network shifted to its own country, which spread over parts of Sumatra, East Java, West Java, and Kalimantan and the island of Bangka itself in the decade of the New Order era until the post-reform era around the 1970s until now. Then, if you look at the historical roots of the odyssey of the intellectual network of the Bangka community boarding schools, especially the types of Islamic boarding schools and their scientific specifications, they are the salafiyah type. Strengthening in the fields of akidah tauhid, fiqh, al-Qur'an, nahwu, sorf, and interpretation of hadith is a top priority. Then it developed into a combination and modern type of Islamic boarding school as an addition to other sciences. The intellectual network paths and scientific specifications of the pesantren of the Bangka community can be illustrated in the following diagram.

Diagram 2. Islamic Boarding School Learning Intellectual Network Bangka Society 1910-present

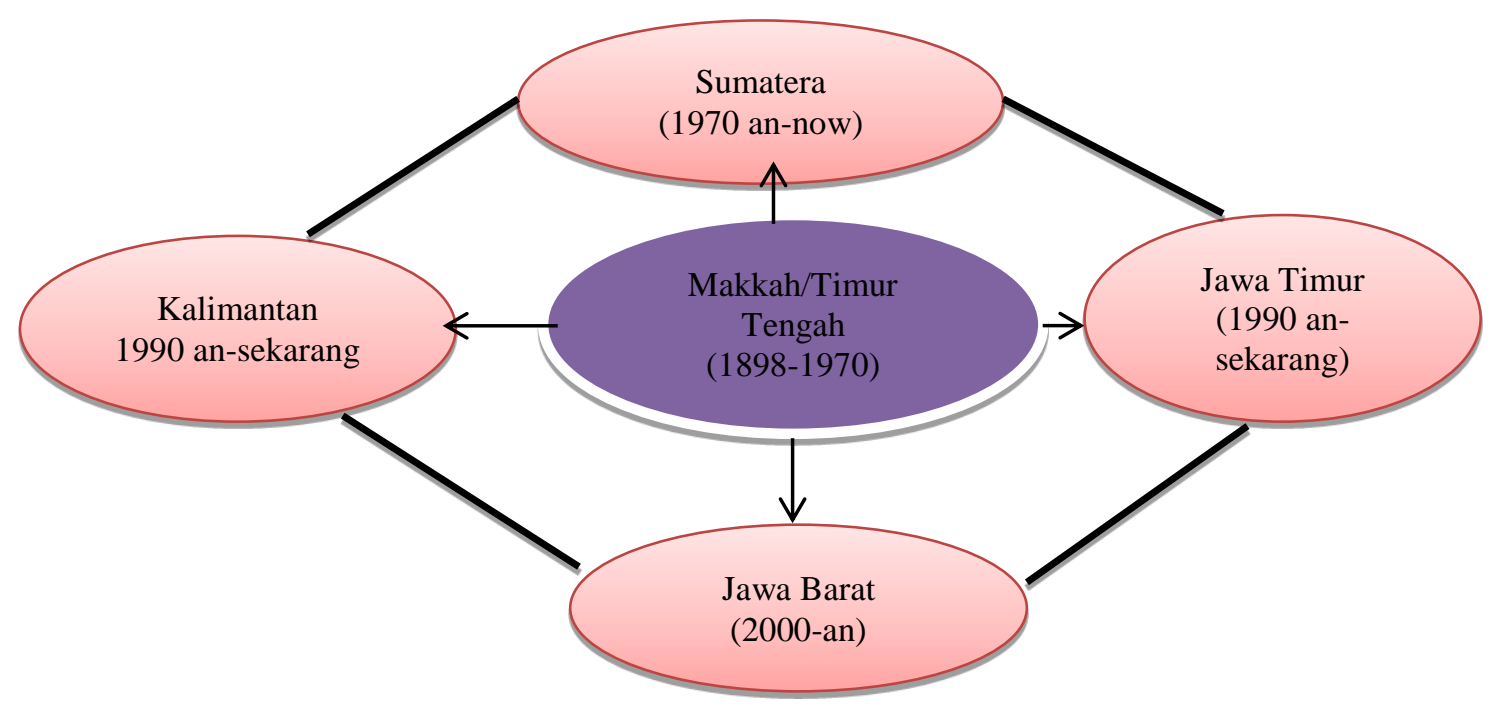

Diagram 3. Mapping by Type of Islamic Boarding School

Bangka Community Learning Intellectual Network 


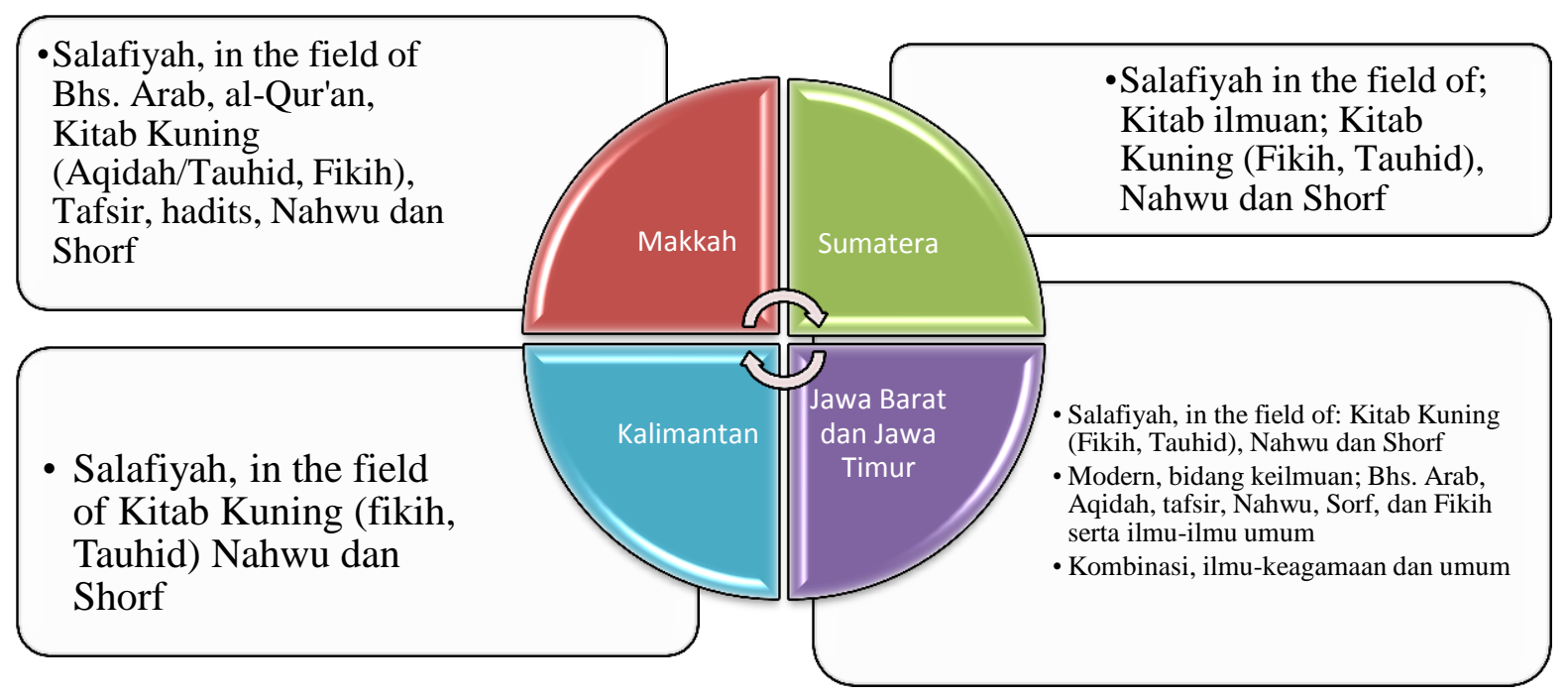

\section{F. Conclusion}

The historical journey of institutional boarding schools in the province of the Bangka Belitung islands has been dynamically continuous from the preindependence period to the post-reformation period. This historical span has lasted for almost 160 years until now. It still exists to take part amid the plurality of the people of Bangka Belitung. A traditional Islamic education institution for the Bangka community, namely the Sitting and reading the Koran. Then later changed the system to a classical system in the form of an Arabic school or madrasah. Departing from the classical Arab schools or madrasahs system by combining several madrasas such as TPA, MDA, MI, MTs, and MA into Islamic boarding schools.

Based on the historical dynamics of traditional Islamic educational institutions (reciting the Koran sitting/reciting the scriptures) and then Arabic schools/madrasah, this is the formation of Islamic boarding schools in the archipelagic province of Bangka Belitung. The institutional hierarchy indeed refers to the intellectual network process that occurs. The intellectual network was interwoven and formed from scholars who learned from Mecca and the Middle East, such as Shaykh Abdurrahman Siddik. Then after that is the network of the Bangka community who went on the pilgrimage last night by settling in a city as holy as Makkah and the Middle East to study. It was from them that the intellectual 
network of the pesantren in the archipelago Province of Bangka Belitung was established.

\section{References}

Abdullah Idi, Bangka Sejarah Sosial Cina Melayu, (Yogyakarta: Tiara Wacana, 2011),

AH. Johns, From Coastal Settlement to Islamic School and City: Islamization in Sumatera, The Malay Peninsula, and Java, in J Fox (ed.) Indonesia: The Making of A culture, School Seminar Series No.2, (Canberra: Research School of Pacific Studies, ANU, 1980), h. 168. Lihat pula Dhofier, Tradisi Pesantren ..., h. 129

Akhmad Elvian, Memperkuat Jati Diri Melayu, dalam Mutiara Negeri Melayu, (Bangka Belitung: Madania Center Press, 2019

Haidar Putra Daulay, Sejarah Pertumbuhan dan Pembaruan Pendidikan Islam di Indonesia, Cet. 5, (Jakarta: Prenada Media Group, 2018),

M. Arifin Mahmud, Sejarah dan Budaya Bangka, (Sungailiat: Materi Sarasehan Seni dan Budaya Daerah Kabupaten Bangka, 1994),

Ma'moen Abdullah et al., Sejarah Daerah Sumatera Selatan, (Palembang: Proyek Inventarisasi dan Pembinaan Nilai-Nilai Budaya Provinsi Sumatera Selatan, 1991), h. 108

Manfred Ziemek, Pesantren dalam Perubahan Sosial, (Jakarta: P3M, 1986),

Mely Agustini dkk, Statistik Daerah Provinsi Kepulauan Bangka Belitung Tahun 2020, (Penerbit BPS Provinsi Kepulauan Bangka Belitung, 2020),

Mely Agustini dkk, Statistik Daerah Provinsi Kepulauan Bangka Belitung Tahun 2020, (Penerbit BPS Provinsi Kepulauan Bangka Belitung, 2020),

Nurcholish Madjid, Bilik-Bilik Pesantren Sebuah Potret Perjalanan, (Jakarta: Paramadina, 1997),

Zamakhsyari Dhofier, Tradisi Pesantren Studi Pandangan Hidup Kyai dan Visinya Mengenai Masa Depan Indonesia, cet. 2, (Jakarta: LP3ES, 2011), h. 101

Zamakhsyari Dhofier, Tradisi Pesantren, (Jakarta: LP3ES, 1984),

Zulhimma, Dinamika Perkembangan Pondok Pesantren Di Indonesia, Jurnal Darul 'Ilmi Vol. 01, No. 02 2013, 
Zamakhsyari Dhofier, Tradisis Pesantren Studi Pandangan Hidup Kyai dan Visinya Mengenai Masa Depan Indonesia, (Jakarta: LP3ES, 2011), h. 54

Zaman Zahri, Penuturan Lisan Tentang Sejarah Ngaji Duduk dan Pesantren di Desa Kemuja Bangka, 2020,.

Zaman Zahri, Saksi Sejarah dan Tenaga Pendidik Pesantren Al-Islam Kemuja, Wawancara, Pangkalpinang, 25 Maret 2020

Zaman Zahri, Senior dan penyejarah Pondok Pesantren Al-Islam, Wawancara, Pangkalpinang, tanggal 25 Februari 2020. Lihat pula Zulkifli, Kontinuitas Islam

Zaman Zahri, Tenaga Pendidik Pesantren Al-Islam Kemuja, Wawancara, Pangkalpinang, 25 Maret 2020

Zulkifli, Kontinuitas Islam Tradisional di Bangka, cet. I, (Sungailiat: Shiddiq Press, 2007), 